\title{
Correction: Impacts of hypoxia on estuarine macroinvertebrate assemblages across a regional nutrient gradient
}

\author{
Michael R.S. Coffin ${ }^{\mathrm{a} \star}$, Simon C. Courtenay ${ }^{\mathrm{ab}}$, Kyle M. Knysh ${ }^{\mathrm{a}}$, Christina C. Pater ${ }^{\mathrm{a}}$, and \\ Michael R. van den Heuvel ${ }^{\mathbf{a}}$ \\ ${ }^{a}$ Canadian Rivers Institute, Department of Biology, University of Prince Edward Island, Charlottetown, \\ PE C1A 4P3, Canada; ${ }^{b}$ Canadian Rivers Institute, Canadian Water Network, School of Environment, \\ Resources and Sustainability, University of Waterloo, Waterloo, ON N2L 3G1, Canada
}

*mikerscoffin@gmail.com

Re: Coffin MRS, Courtenay SC, Knysh KM, Pater CC, and van den Heuvel MR. 2018. Impacts of hypoxia on estuarine macroinvertebrate assemblages across a regional nutrient gradient. FACETS 3: 23-44. doi:10.1139/facets-2017-0044

On page of 40 the originally published article, the title of the journal in the following reference was incorrectly cited as Pollution Bulletin. The correct title is Marine Pollution Bulletin.

Coffin MRS, Courtenay SC, Pater CC, and van den Heuvel MR. Submitted. An empirical model using dissolved oxygen as a proxy for eutrophication at a regional scale. Pollution Bulletin.

The corrected (and updated) reference is shown here:

Coffin MRS, Courtenay SC, Pater CC, and van den Heuvel MR. 2018. An empirical model using dissolved oxygen as an indicator for eutrophication at a regional scale. Marine Pollution Bulletin, 133: 261-270. PMID: 30041313 DOI: 10.1016/j.marpolbul.2018.05.041

The article has been corrected accordingly.

\begin{abstract}
Citation: Coffin MRS, Courtenay SC, Knysh KM, Pater CC, and van den Heuvel MR. 2019. Correction: Impacts of hypoxia on estuarine macroinvertebrate assemblages across a regional nutrient gradient. FACETS 4: I61. doi: 10.1 139/facets2019-0022

Received: May 13, 2019
\end{abstract}

Accepted: May 13, 2019

Published: May 22, 2019

Copyright: (c) 2019 Coffin et al. This work is licensed under a Creative Commons

Attribution 4.0 International License (CC BY 4.0), which permits unrestricted use, distribution, and reproduction in any medium, provided the original author(s) and source are credited.

Published by: Canadian Science Publishing 